\title{
The Political Trends of the Youth of University in Palestine and Algeria: A Comparative Field Study
}

\author{
Saida Khedrane ${ }^{1} \&$ Al-Sayed Abdel-Mottaleb Ghanem ${ }^{2}$ \\ ${ }^{1}$ Faculty of Economics and Political Science, Cairo University, Cairo, Egypt \\ ${ }^{2}$ Faculty of Economy and Political Science, Cairo University, Cairo, Egypt \\ Correspondence: Saida Khedrane. E-mail: Saidamohamad48@gmail.com
}

Received: October 5, 2017

Accepted: October 29, $2017 \quad$ Online Published: November 28, 2017

doi:10.5539/ass.v13n12p160

URL: https://doi.org/10.5539/ass.v13n12p160

\begin{abstract}
The current study aims to measure the level of political trends of University's youth in Palestine and Algeria. A questionnaire has been used for collecting data about the opinions of a sample of students at Al - Najah National University of Palestine and Kasdi Merbah University of Algeria enrolled in the academic year 2015- 2016. The study has adopted the Statistical Package for the Social Science (SPSS) for the purposes of measurement. It has concluded that the nature of the political trends of the university youth at the Palestinian University tends to the negative level more than the positive one due to the conditions of occupation and political instability in the Palestine arena. On the other hand, the nature of the political trends of the university youth in the Algerian university tends to the positive level more than the negative one. This is due to the state of political stability characterized by the political system in Algeria, as well as the political reforms that have positively affected the nature of the political trends of the university youth since President Abdul Aziz Bouteflika took power in Algeria, down to creating a higher council for youth in the new constitutional amendment of 2016 .
\end{abstract}

Keywords: Political Trends, Political Tendencies, Political Belief, Palestine, Algeria, Youth

\section{Introduction:}

The political trends of young people are an urgent and important issue because they convey the facts according to the viewpoint of their owners. Political trends are one of the most important outcomes of the process of political socialization. They are also the main momentum for the individual behavior in society. Alport was one of the first people who interested in the concept of trend. He defined it as one of the cases of mental and neural preparedness that is organized by experience. It directs the individuals' responses of different things and situations (Al- Abaidi, 2009), whether negatively or positively, towards a situation in the environment that determines positive or negative values to this conduct. There is a view that trend is a psychological readiness which is based on what a person goes through (Seidik, 2012). Thus, a person constitutes an opinion about certain thing, event or issue, either by acceptance, rejection or opposition, because he was faced by a particular experience relating to that thing, event or issue. It is also characterized by being acquired and relatively stable (Nashwan, 2001). According to some researchers, trend is a disciplined and organized determinant for individual's behavior, as well as it is an organized and consistent methods of thinking, behavior and reactions towards people, groups, and social and political issues (Zu'bi, 1994). According to many scholars, it is one of the most important components of the individual's personality, as it constitutes the real component that directs the behavior of the individual and drives him in situations that require responding to any matter with acceptance or rejection (Al- Rawadbeh, 2000). It is an indicator of the value or belief behind it (Marshall, 2000). For this, a large number of political psychology researchers confirm that political trends directly affected the vision of individuals of the objectives and programs of political forces, organizations and parties, and promote their belonging to some of them (Hijazi, 2009). Additionally, they affected individual's response to political issues that require a reaction according to personal experience (Abdali, 2003). This matter creates impressions and feelings towards the political system and its roles, men and achievements. Such feelings and impressions may be attractive, repulsive or unacceptable (Sharap, 1998). This is why Gabriel Almond described political trends as individual's view of the political system in its various parts and his role in the system as a political actor (Almond \& Verba, 1965). Based on this vision, he pointed out four dimensions: first, the citizen's vision of the political system in general, the extent of his national feeling, and his vision of the nature of the state to which he belongs. Second, the functions of inputs have been evaluated by the citizen. This is done by determining the extent of his sensitivity to his effectiveness and his impact on governmental decisions whether locally or nationally. Third, the citizen's vision and response to the outcomes of the political system by knowing his views on government's decisions and policies. Fourth, the view of the citizen of his role as a partner in the political system and his ability to affect the decision- making and government's policies

We mean the questionnaire of the scientific article by Yaser Nimer Hamed entitled:" Political Trends among the Students of the Palestinian University: With applying to the Students of Al-Najah National University. Al-Aqsa University Journal, 19(2), 327-357. (2015). 
(Almond \& Verba, 1965). According to Almond, political tendencies such as trust in institutions and incumbents are highly variable due to differences in the rates of political performance (Almond, 1990). Ghanem attributed this to several factors, which affect the citizen's attitudes towards political power (Ghanem, 1983). These factors are the following:

1- Political effectiveness: it means the individual's assessment of his skills and effectiveness in order to understand and deal with politics.

2- Political engagement: it means that the citizen feels his active political role in society.

3- Political uncertainty: it means citizens' little confidence in the existing political institutions and their performance and effectiveness (Al- Abaidi, 2009).

4- Approaching the political process: it means that the citizen is aware of the positive and negative effects left by the political process on their daily lives, in the sense of appreciation of the individual's perception of the political system and what this system offers.

5- Political satisfaction: it means that the actions of the national government or the local one improve the citizen's conditions.

Thus, trend is the process of linking knowledge, emotions, and behaviors together in an organized structure, although these three components are not fully consistent with each other. Concurrently, the importance of the emotional element has been increasingly emphasized because it is the strongest among the components of the psychological trend on the one hand and it is closely related to individual's exhaustive energies on the other. The process of the change of trends is influenced by a set of factors: Some of these factors concern the individual himself. When individual is more open to experiences, he is more receptive to adjust his trends. The other relate to the matter of trend itself. When the matter is more connected to the individual and his personality, trend is less likely to be altered or modified (Nchwati, 1996).

Studies related to the role of Palestinian and Algerian youth as actors in political life and their relationship to political system have shown that there is a relationship characterized by a negative attitude. This is clearly demonstrated in the youth's meager participation in political life, especially the national elections of the two countries. This is due to the youth's feeling that political systems cannot formulate new public policies that meet their demands. Therefore, confidence in political systems has been badly shaken. Also, apathy and political alienation became prevalent feelings among young people.

The political conditions were strained in Palestine. However, radical changes in the political conditions have been occurred in Algeria. The current political leadership headed by President Abdul Aziz Bouteflika has done its best to restore the confidence of the young people in the political system by making a set of reforms at various levels. The most important of these reforms was the empowerment of young people and making them a key partner in the formulation of public policy, leading to the establishment of a Higher Council for Youth in the last constitutional amendment in 2016 (Law No. 16- 01, 2016). Therefore, the study seeks to investigate the nature of the political trends of Palestinian and Algerian university youth and tries to compare the two cases.

The argent reasons for comparing the two cases in terms of the political trends of youth are determined in the following:

\subsection{Similarity}

There is a similarity in:

* The nature of government order: both countries adopt the democratic system and elections to get to power and its deliberation.

* Similarity in the sample: the two samples represent the university youth in Palestine and Algeria.

* Similarity in political culture of the youth of the two countries.

\subsection{Difference}

Despite the similarity of the government system in both countries, the situation of each regime is different from the other. The Palestinian political system is characterized by political instability, while the situation of Algerian political system is characterized by political stability.

Accordingly, the research aims to measure the level of political trends of university youth in Palestine represented by Al- Najah National University's youth, and in Algeria represented by Kasdi Merbah's youth. Also, the study tries to clarify the nature of these trends by measuring feelings of suspicion, political trust, and political ability and effectiveness towards the system and the political process, and towards also the young people as a political actor in making the public policies.

In order to reveal the nature of the political trends of youth, the predicament of study was determined in the following main question: what is the nature and level of the political trends of the university youth in Palestine and Algeria towards the political system and its institutions and the political process, and towards youth themselves as actors?

In order to answer this question, the study presented the following two preliminary hypotheses: 
* University youth in Palestine and Algeria still have a low degree of political trust in the political system and its institutions, and in the political process.

* University youth in Palestine and Algeria still have a weak degree towards the competence and effectiveness of the political system and its institutions and towards themselves as actors in public policy- making.

To achieve the objectives of the study, the analytical descriptive, the comparative and survey approaches are adopted by using a survey questionnaire measuring the nature of the political trends of university youth in Palestine (.) represented by students of AL- Najah National University, and in Algeria ${ }^{(. .)}$represented by students of Kasdi Merbah University at Ouargla (South Algeria) ${ }^{(\cdots)}$. The questionnaire has been distributed by a random sample of 600 students enrolled in the 2015/2016 academic year. Students were from theoretical and practical collages. The reliability and stability of the sample has been verified by using the measure of Cronbach's Alpha. The degree of the stability of political trends measure in all its indicators amounted $0,922^{(\cdots . .)}$, which means it is reliable in measurement. The questionnaire was also judged by Professors specializing in political science, sociology and statistics (…). The collected data have been analyzed and processed by using Statistical Packages for Social Science (SPSS). The study has divided the levels of political trends into three levels: weak, medium and good ${ }^{(*)}$.

\section{First, measuring the trends of suspicion and confidence in the system and its institutions and in the political process}

To determine the level and nature of political trends for suspicion and confidence, this indicator has been divided into phrases measuring confidence and suspicion in the political system and its leader as symbols of it, and other phrases measure confidence and suspicion in the system's institutions, down to phrases that measure the trends of young people in the political process, the degree of confidence in its strength and the extent of submission to it (Abdul Jalil, 2014). The sense of mutual political trust between the political system and the individual make him ready to cooperate with others in society and work on the basis that he has an important role no less important than political officials' role (Sirag, 1998), raising the level of loyalty and association with the system. However, the lack of confidence in the system and the poor performance and effectiveness of its existing political institutions (Ghanem, 1979) has a negative effect, which increases the sense of alienation and psychological isolation from the system, additionally, the lack of sense of responsible citizenship with its rights and obligations (Dahl, 1966). In order to verify this, the researcher assumes, based on the evidence of many studies on youth and politics in Palestine and Algeria, that university youth in Palestine and Algeria still have a low degree of political confidence in the political system and its institutions, as well as in the political process.

The field results of Palestine students from Al- Najah National University have showed a high level of suspicion and mistrust in the Palestinian political system and its institutions (Abu Hamid, 2015). On the other hand, the field results shown in Table (1) for Algerian students from Kasdi Merbah University have illustrated the high level of trust in the political system and its institutions ${ }^{(* *)}$. Some $32,3 \%$ of the respondents were of good grade, $43 \%$ were of a medium degree, and only $24,7 \%$ were of a low degree of trust in the political system and its institutions.

Table 1. Measuring trends of suspicions and trust in the system and its institutions.

\begin{tabular}{cc}
\hline Measuring trends uncertainty and trust in system and its institutions & percentage \\
\hline Weak $(0-1.6)$ & $24.7 \%$ \\
Medium $(1.7-3.3)$ & $43 \%$ \\
Good $(3.4-5)$ & $32.3 \%$ \\
Total & $100 \%$
\end{tabular}

The low level of confidence in system and its institutions among the sample of Al- Najah National University in Palestine attributes to the political division since 2007. This division has begun to constitute a general opposed trend due to its negative impact left on Palestinian's life. Locally, Palestinians have been severely affected by this division because it served as an obstacle to civil and political freedom in both the West Bank and Gaza Strip. It has contributed to the emergency of extremist currents and has encouraged the spread of political violence. Such division also has increased the status of discrimination based on the political affiliation that led to inequality between Palestinian citizens. Furthermore, it has obstructed the role of many institutions such as the parliament, which is no longer able to play its legislative and supervisory roles (Abu Hamid, 2015). In the Algerian case, the high level of positive trend towards confidence in the political system and its institutions among the university youth in Algeria reflects their understanding of the political system which works for the benefit of the people and its institutions, especially the judiciary. These institutions enjoy integrity and are keen to preserve all the rights and duties of all Algerian citizens. The study attributes this matter to the significant change occurred in the method of political action since 1999. Such method adopted by the government aimed to ensure the independence of judiciary, reform the state's institutions and consolidate democracy (Kadari, 2005).

On the other hand, the results of the field research regarding confidence in the political process confirmed that the predominant trend among the sample of the students of Al- Najah National University in Palestine was high (Abu Hamid, 2015). While the results of the field research shown in table (2) confirmed that the predominant trend among the sample of the students of Kasdi Merbah University in Algeria was positive ${ }^{(* * *)}$. The degree of confidence in the 
political process of about $41.7 \%$ respondents was good, $32.3 \%$ was medium, and $26 \%$ was weak.

Table 2. Measuring trends of uncertainty and trust in the political process.

\begin{tabular}{cc}
\hline Measuring trends of uncertainty and trust in political process & percentage \\
\hline Weak $(0-1.6)$ & $26 \%$ \\
Medium $(1.7-3.3)$ & $32.3 \%$ \\
Good $(3.4-5)$ & $41.7 \%$ \\
Total & $100 \%$ \\
\hline
\end{tabular}

The low level of confidence in the political process reflects the awareness of the students. Israel has exploited the state of political division in the Palestinian arena by imposing punitive practices against Palestinian in Gaza Strip, which served as an obstacle to unity, peace, tolerance and political freedom.

In their responses to the paragraphs of the questionnaire, the students also stated that the completion of the Palestinian reconciliation is the best option to pressure Israel and support the Palestinian negotiator within the framework of the peace process. Simultaneously, they expressed their satisfaction with the university's policies that allow them to participate in non- academic activities within the university, promote the values of belonging, freedom and social justice, and provide them with opportunities to participate in political conferences and seminars related to the ArabIsraeli conflict (Abu Hamid, 2015). In contrast, the high level of those who believe that the political process, in general, is fair and transparent (Abdel Halim, 2004) reflects the awareness of respondents of Kasdi Merbah University of the importance of the integrity of the political process. Some people see the opposite is true. However, the study attributes the high positive level to the political reforms adopted by President Abdelaziz Bouteflika such as the amendment of the election law, the transparency of the political process in general (Karbousa \& Aknoush, 2005), and making the citizen a partner in the political process. According to results, the hypothesis of the Palestinian case will be accepted, but the hypothesis of the Algerian case will be rejected.

\section{Second, measuring the trends of ability and effectiveness towards the system and its institutions and young people as a political actor.}

In order to uncover the level and nature of the trends of university youth in Palestine and Algeria towards the political effectiveness and competence, this indicator is divided into phrases that measure the feelings of university youth towards effectiveness and competence of the political system and its institutions, and towards themselves as political actors. The first means the the view of individual about power, whether he see it as necessary for him or not, and whether it benefits him or benefits only those occupying key positions (Noir, 2001). In addition, approaching the political process plays a major role in the citizen's awareness of the positive and negative effects of the political process on its daily life. Put differently, assessing the individual's perception of the political system and what it has to offer gives him the feeling that the actions of the national government or the local one are improving his conditions (Ghanem, 1983). The second is the tendency of the individual towards himself as a political actor, which means that the individual has the ability to impact in the course of political life by the constructive criticism of any political official or showing his opinion on various issues, with the conviction that his opinion is valuable to the decisionmaker. In this vein, it is possible to distinguish between individual's sense of being a political actor who is capable of making an actual change or his sense of incapacity where political decisions are issued and his opinion has no effect in any way even slightly (Ghanem, 1981). If the individual's opinion and criticism does not affect the course of political events or this effect is very limited, he will tend to negativity and apathy, and vice versa. If the individual's opinion was influential, he would become more interested in politics (Garaybeh \&Nofal, 2004). In order to measure the nature of these trends, the study also hypothesized that university youth in Palestine and Algeria still have a weak degree towards the competence and effectiveness of the political system and its institutions and towards themselves as actors in public policy- making.

The statistical results have shown that the level of the positive trend of the indicator of political effectiveness and competence of university youth in Palestine towards the Palestinian political system and its institutions was low (Abu Hamid, 2015). As for respondents' opinions at Kasdi Merbah University, we find that the field results shown in table (3) recorded a high level of the positive trend of the political effectiveness and competence of university youth in Algeria towards the system and its institutions ${ }^{(* * *)} .35 .8 \%$ of respondents were at a good level, $41.9 \%$ were at a medium level, and $22.3 \%$ were at a weak level.

Table 3. Measuring trends of competence and effectiveness towards the political system and institutions

\begin{tabular}{cc}
\hline measuring trends of competence and effectiveness towards the political system and institutions & percentage \\
\hline Weak $(0-1.6)$ & $22.3 \%$ \\
Medium $(1.7-3.3)$ & $41.9 \%$ \\
Good $(3.4-5)$ & $35.8 \%$ \\
Total & $100 \%$ \\
\hline
\end{tabular}


The study found that the weak percentage of the confidence of Al- Najah National University's students in the efficiency of the Palestinian system and its effectiveness in achieving the peace process and ending the state of division is due to inequality in power balance between the Palestinian political system and Israel. According to Palestinians, there has been no change in the peace process since 1993. Israel has worked to confiscate more lands and intensified the construction of settlements in the Palestinian territories in order to impose fait accompli policy, which prevents the establishment of Palestinian state. It wants the peace process to achieve its goals by expanding and further confiscating Palestinian territories, which is an obstacle to peace (Abu Hamid, 2015). On the contrary, the level of political competence and effectiveness of university youth in Algeria was high. According to the study, this is due to the political reforms adopted by President Bouteflika, which raised the level of actual performance of political, economic and social institutions (Hamzawy, 2003). The beginnings of the reforms were represented in alleviating the political violence, restoring security, and bringing the administration and institutions closer to the citizens (Tashma, 2010). These previous matters led to meeting the requirements of the citizen, paying off foreign debts, working to absorb unemployment (Khadran, 2012), and seeking to achieve economic development.

In terms of self- orientation as a political actor for Al- Najah National University's respondents, the results of the field research showed a weak level (Abu Hamid, 2015). Thus, the results of the field research in the Algerian case, as shown in table 4, have illustrated the high level of positive trend of respondents towards their political ability and effectiveness ${ }^{(* * * *)} \cdot 41.5 \%$ of respondents have a good level of political ability and effectiveness if the opportunity is given to them to make political decision. The level of the political effectiveness of percentage $30.3 \%$ of respondents recorded a weak level.

Table (4) measuring trends ability and effectiveness of youth as a political actor

\begin{tabular}{cc}
\hline Measuring trends ability and effectiveness of youth as a political actor & percentage \\
\hline Weak $(0-1.6)$ & $28.2 \%$ \\
Medium $(1.7-3.3)$ & $30.3 \%$ \\
Good $(3.4-5)$ & $(41.5) \%$ \\
Total & $100 \%$ \\
\hline
\end{tabular}

The researcher attributes the weakness of the level of orientation towards the self as a political actor for Al- Najah National University to their conviction that they cannot affect decision and policy making. This influence cannot be achieved in light of the continued state of political division in the Palestinian arena. Therefore, they call for negotiations and they believe that negotiations are the best way to achieve are the best way to achieve Palestinian demands and resorting to the United Nations again will siege Israel which leads it to meet the demands of the Palestinians (Abu Hamid, 2015). The study also attributes the high level of positive trends towards the political ability and effectiveness of the university youth's respondents in Algeria towards themselves as political actors or if they are given the opportunity to achieve this and participate in political decision- making to a set of policies and laws adopted by President Bouteflika aimed at empowering young people and making them partners in all fields, especially the political field. Since the hypothesis claimed a weak level of the two cases and the results of the study proved the opposite, the hypothesis would be accepted in the Palestinian case and would be rejected in the Algerian one.

\section{Conclusion}

After reaching the results of the study and the answer of its hypotheses, it has been found that the nature of the political trends of the university youth in Palestine tends to the negative level more than the positive one. This attributes to the conditions of occupation and political instability in the Palestinian arena. In contrast, the nature of the political trends of the university youth in Algeria tends to the positive level more than the negative one. This is due to the state of political stability characterized by the political system in Algeria, as well as political reforms adopted by President Abdul Aziz Bouteflika. These reforms have positively affected the nature of the political trends of university's youth in Algeria. The political system has sought first to achieve internal security and peace by adopting the two harmony and reconciliation laws (Qubi and Bushnaka, 2005). It also has consolidated democracy. Furthermore, it has adopted the policy of good governance the empowering youth and women and involved them in various governance and administration fields (Shibli, 2009), the establishment of the principle of transparency and accountability through approving anti- corruption act (Zarraka, 2007), reforming and developing the economy and tackling the social problems, especially unemployment (Khadran, 2012). In addition, we should not forget the restoration of Algeria's international status (Lunisi, 2000). These reforms made the institutions close to the citizen, and played a positive role in changing the political trends that characterized previously by negative, reluctance and the feeling of political alienation, but characterized now by positivity and participation.

\section{Recommendations}

Based on the aforesaid conclusions, the study set a number of recommendations. They are as follows:

\subsection{As for the Palestine case:}

It is necessary to eliminate the state of acute political division among the Palestinian factions and promote the practices of participation, democracy, tolerance, the abandonment of violence, cooperation and affiliation. This is done by 
holding seminars, conferences, lectures, meetings, discussions and interviews, which enhance student's positive political trends. Thus, students can be rallied around one political will that will enable them to be changed to the best and give them the ability to be influential in political decision- making.

5.2 As for the Algerian case:

In order to preserve these gains, more reforms should be made regarding the political practice and enhancing the status of youth, not only as partners, but also as leaders in the state.

\section{References}

Abd Elgalil, D. (2014). Political Culture of Citizens in Upper Egypt: A Field Study at Bny Ady Village of Assiut Governorate (Unpublished master's thesis). Cairo: Faculty of Economics and Political Science.

Abdel Halim, A. (2004). Algeria: New Presidential Challenges for Bouteflika. Democracy Journal, No. 15, $183-188$.

Abu Hamid Y. (2015). Political Trends of Palestinian University students by Application to Al- Najah National University's Students. Al-Aqsa University Journal, 19(2), 327-357.

Al- Abaidi, M. (2009). Introduction to General Psychology. Jordan: Dar Al- Thaqafa Press.

Al- Abali, S. (2003). Democratic Political Culture of Yemeni Tribes (Unpublished doctoral dissertation). Cairo: Faculty of Economics and Political Science.

Al- Rawadbeh, S. (2000). Trends of Students of Social Studies of Mu'tah University Towards their Field of Specialization. Mu'th Journal for Research and Studies, 15(7), 193-227.

Al- Zu'bi, A. (1994). Foundation of Social Psychology. Sana'a: El- Hakma Al- Yamaneia Press.

Almond, G. \& Verba. S. (19965). The Civil Culture: Political Attitudes and Democracy in Five Nation. Boston: Little Brown and Company.

Almond, G. (1990). Discipline Divided: Schools and Sects in Political Science. London: Sage.

Dahl, R. A. (1996). Political Opposition in Western Democracies. London: Yale University Press.

Ghanim, E. (1979). Political Participation in Egypt (Unpublished doctoral dissertation). Cairo: Faculty of Economics and Political Science.

Ghanim, E. (1981). A Study in Political Development. Cairo: Nahdet Al- Sharq Library.

Ghanim, E. (1983). The Relationship of the Masses to the Political System. Cairo: Dar Al- Cahara Press.

Gharaybeh, M. (2004). Political Culture of Jordanian Students in Secondary School: Comparative Study for Students at Public and Foreign Schools. Al- Nahda Journal, No. 19, 5-33.

Hamzawy, A. (2003). Between the Slogan and the Truth: Speeches and Reform Programs in a Changing World. Cairo: Center for Studies and Researches of Developing Countries.

Hijazi, I. (2009). Participation of University Youth in political Life (Unpublished master's thesis). Cairo: Faculty of Economics and Political Science.

Kadari, H. (2005). The Concept of Good Governance. Parliamentary Thought Journal, No. 8, 82-29.

Karbousa, A. \& Aknoush, N. (2005, December). The Manifestations of Democratic Transformation during the Reign of President Bouteflika. Paper Presented at the First Forum on Democratic Transformation in Algeria.

Khadran, S. (2012). The Role of Political Leadership in Managing the Political Violence in Algeria from 1999 to 2010 (Unpublished master's thesis). Cairo: Institute of Arab Research and Studies.

Lounissi, R. (2000). Algerian in the Whirlpool of the Conflict between the Military and Politicians. Algeria: Dar AlMaarifah.

Marshall, G. (2000). Encyclopedia of Sociology (Vol. 1., pp. 200-201). (El- Gohary, M. et.al., Trans.). Cairo: Sureme Council of Culture.

Nashwan, Y. (2001). The New in Science Education. Jordan: Dar Al- Furqan press.

Nashwati, A. (1996).Educational Psychology. Jordan: Dar Al- Furqan.

Noir, A. (2001). Teachers and Politics in Egypt. Cairo: Center for Strategic Studies.

Qubi, A. \& Boushnaka, S. (2005). The Management of the Political System of Political Violence in Algeria (19882000) Al-Paheth Journal, No. 3, 127-140.

Sharap, N. (1998). Political Development: Study in Theories and Issues. Aman: Palestine's Library.

Shibli, K. (2016).The Political Empowerment of Algerian Youth in Light of Current Variation: Constitutional Right or Strategic Option. Politics and Law Journal, No. 14, 145-156.

Siddiq, H. (2012). Trends from Sociology Perspective. Damascus University Journal, 28 (3), 229 - 322.

Sirag, S. (1998). Public Opinion: its Components and its Impact on Cotemporary Political Systems. Cairo: General Authority for Books. 
Tachma, B. (2010). Good Governance and the Problem of Building of Capabilities of Local Management in Algeria. Al- Tawasol Journal, No. 26, 25- 52.

Zarraka, F. (2007, April). Corruption in Algerian Society and Strategies to reduce it. Paper Presented at the International Forum on Good Governance and Change Strategies in the Developing World, Setif, Algeria.

\section{Notes}

We mean the questionnaire of the scientific article by Yaser Nimer Hamed entitled:" Political Trends among the Students of the Palestinian University: With applying to the Students of Al- Najah National University.

The questionnaire consist of ( 25 phrases) divided into three axes: the first ( 3 phrases), especially the student's data (collage, gender, level of study). The second axis includes ( 8 phrases) that measure the confidence and doubt in the political system and its institutions, and the political process. The third axis includes (14 phrases) that measure the indicator of political competence and effectiveness in the political system and its institutions, and the youth as a political actor.

Kasdi Merbah University is located in Ouargla governorate in the south east of Algeria, $800 \mathrm{~km}$ away from the capital, Algeria. the first nucleus Kasdi University was established in September 1987.it has witnessed many transformations in its organizational and pedagogical structure. According to executive decree No. 13 - 100 of 2 Jumada Al- Awal, 1434, corresponding to March 14, 2013, amended and supplemented by executive decree No. 01-210 of Jumada AlAwal, 1722, corresponding to July 13, 2001, Kasdi Merbah University currently consists of 10 theoretical and practical colleges, where they receive students from all over the country.

The measure of Cronbach's Alpha is used to measure the stability of instrument, and stability and accuracy of questionnaire (the stability accuracy of the study means it measure the questionnaire's questions in terms of its actual measurement and the clarity of questionnaire and its terms and definitions for those who will be included in the questionnaire and will be valid for the statistical analysis). When the measure of Cronbach's Alpha approach to (1), the stability of instruments is stronger.

The arbitration of questionnaire: Cairo University, Prof Dr. Al-Sayed Abdul Mutallab Ghanem, Prof. Dr. Safi Al- Din Kharbush, Prof. Dr. Ahmed Magdey Hijazi, Prof. Dr. Ahmed Gad. From Kasdi Merbah University: Prof. Dr. Adam Kabbi.

*In order to build the indicators of the political trend measure, the study has been based on determining how weights are given to these indicators because weights have a profound impact on the results of the composite indicator. The method of equal weight is used in this study. This method is based on the same weight for each of the indicators because there is no clear evidence of the different importance of each of these indicators, and then convert this indicator to a normative indicator, meaning that its value ranges from $1-5$ by the normative indicator $=($ the original value of the indicator- the minimum indicator) / range. By aggregating these indices and dividing them by their numbers, we obtain the composite indicator. This indicator is a standard of between (1- 5), then redistributed to three levels (good: strongly agree, agree) (medium: natural), (Weak, I disagree, strongly, disagree).

** With a stability of 0.769 . The credibility and stability of the confidence and uncertainty indicator in the political system and its institutions were verified using the measure of Cronbach's Alpha.

*** With a stability of 0.758 , the validity and stability of the confidence and uncertainty indicator in the political process was verified using the measure of Cronbach's Alpha.

**** With a stability of 0.885 . The credibility and stability of the political competence and effectiveness indicator in the system and its institutions were verified using the measure of Cronbach's Alpha.

$* * * * *$ With a stability of 0.777 , the validity and stability of the youth's competence and effectiveness indicator was verified as a political actor by using the measure of Cronbach's Alpha.

\section{Copyrights}

Copyright for this article is retained by the author(s), with first publication rights granted to the journal.

This is an open-access article distributed under the terms and conditions of the Creative Commons Attribution license (http://creativecommons.org/licenses/by/4.0/). 